San Jose State University

From the SelectedWorks of Amy Leisenring

2008

Controversies Surrounding Mandatory Arrest Policies and the Police Response to Intimate Partner Violence

Amy Leisenring, San Jose State University

Available at: https://works.bepress.com/amy_leisenring/4/ 


\title{
Controversies Surrounding Mandatory Arrest Policies and the Police Response to Intimate Partner Violence
}

\author{
Amy Leisenring*
}

San Jose State University

\begin{abstract}
Since the early 1970s, the efforts of the battered women's movement have led to many changes in the criminal justice response to intimate partner violence (often referred to more broadly as 'domestic violence') in the USA. One important reform has been the implementation of policies that encourage or mandate the arrest of offenders. However, mandatory arrest policies have been hotly debated by scholars, activists, and criminal justice system officials. In this article, I review the recent changes to the ways in which police officers respond to intimate partner violence and discuss the controversies surrounding these changes in light of recent research. I briefly consider why the literature on this topic has produced such contradictory findings and I discuss several actions that need to be taken in order to improve police response to intimate partner violence and better meet the needs of battered women.
\end{abstract}

\section{Introduction}

Understandings of and responses to violence against women by an intimate partner have changed drastically in the last several decades in the USA. While in the 1960s, intimate partner violence was primarily understood as a personal and private issue and was largely ignored by the police and criminal justice system, it is now viewed as a major social problem and is taken much more seriously. Pressure from feminist groups and battered women's advocates has led to numerous reforms within the criminal justice system. One of the most significant reforms has been the implementation of policies that encourage or mandate the arrest of offenders, often referred to as 'mandatory arrest policies'. (Many jurisdictions have also adopted 'no-drop' prosecution policies that encourage or mandate the prosecution of offenders but a discussion of such policies is beyond the scope of this paper.) Mandatory arrest policies have been the source of much controversy and debate; researchers, activists, victim's advocates, policy-makers, and law enforcement officials disagree about the effectiveness of such policies and the ultimate effects that they have on the lives of the women that they were designed to protect. 
In this essay, I first discuss the ways in which intimate partner violence has been defined and conceptualized. Next, I review the changes to the police response to intimate partner violence in the last four decades and discuss the social factors that have influenced these changes. I then examine some of the current debates surrounding mandatory arrest policies and discuss what existing research can tell us about the consequences and implications of these policies. Finally, I argue that uniform laws such as mandatory arrest policies do not take into account the different types of intimate partner violence that exist and thus cannot possibly address the needs of all abused women. I make several suggestions regarding what is needed to improve the police response to intimate partner violence.

\section{Problems with defining and conceptualizing intimate partner violence}

Within heterosexual relationships, are men more likely to be the perpetrators of intimate partner violence or do men and women use violence with equal frequency? Scholars have disagreed about the extent to which intimate partner violence is a gendered phenomenon. In general, there are two sides to this debate (for an in-depth discussion about this debate, see Archer 2000). Some researchers cite evidence that demonstrates that women are primarily the victims of men's violence (Belknap 2001; Dobash et al. 1992). Others point to evidence that shows women's rates of violence in relationships to be comparable to men's (Straus 1999). There is some evidence that different measurement instruments and sampling strategies produce different rates of men's and women's use of violence (Archer 2000; Belknap 2001; Johnson 2005).

Johnson (2006) also suggests that the majority of studies fail to recognize that there are different types of heterosexual intimate partner violence, primarily distinguished between the 'degree of control present' (p. 1006). (For Johnson, control tactics include threats, economic control, use of privilege and punishment, using children, isolation, emotional abuse, and sexual control.) The four types of violence Johnson has identified are (i) situational couple violence where one member of the relationship is violent and noncontrolling and the other member is nonviolent or is violent and noncontrolling; (ii) violent resistance where one partner is violent and controlling and the other partner is violent and noncontrolling; (iii) intimate terrorism where one partner is violent and controlling and the other partner is either nonviolent or violent and noncontrolling; and (iv) mutual violent control where two violent and controlling people are paired with each other. According to Johnson (2006), research demonstrates that men are significantly more likely to engage in intimate terrorism, women are significantly more likely to engage in violent resistance, and men's and women's participation in situational couple violence and mutual violent control is fairly equal. Furthermore, he argues that the frequency and 
severity of violence involved in intimate terrorism is more severe than in the other types. Thus, Johnson concludes that while some types of violence are nongendered, intimate terrorism - the most serious type of violence - is highly gendered as it is primarily perpetrated by males.

Clearly, how violence is defined and operationalized within a research study impacts the findings of the study. As Johnson (2005) argues, researchers' failure to take into account the different types of intimate partner violence when designing and conducting their studies will result in 'errors of fact' in their findings. These errors of fact lead to differences in how both researchers and those who work with battered women view and define intimate partner violence and the types of intervention strategies that are developed. The literature that I review in this manuscript does not employ a uniform definition of violence. In fact, scholars have disagreed about how to name the social problem of women who are abused by an intimate partner or ex-partner (see Belknap 2001 for discussion). Researchers use terms such as 'family violence', 'intimate partner violence', 'woman battering', and 'domestic violence'. I use the term 'intimate partner violence' in my discussion of this topic. While the majority of studies that I examine in this literature review are not based on a distinction between types of violence as Johnson $(2005,2006)$ advocates, arguably most of the authors of these studies assume intimate partner violence to be a gendered phenomenon in which men are primarily the perpetrators and women are primarily the victims (i.e. 'intimate terrorism' in Johnson's typology).

\section{The police response to intimate partner violence: an historical overview}

Throughout history, intimate partner violence has been permitted - if not encouraged - in virtually every culture (Schneider 2000). Early Roman law gave men ownership of their wives and allowed them to do whatever they wished with their property (Gosselin 2000; Ogle and Jacobs 2002; Schneider 2000). According to the Catholic Church's Rules of Marriage in the 15th century, 'wife beating showed the husband's concern for the wife's soul' (Schneider 2000, 13). Such philosophies shaped early American legal thought - prior to the mid-1800s in the USA laws existed that allowed for wife beating (Gosselin 2000; Schneider 2000). During the late 19th century, women in the first wave of the feminist movement questioned men's use of violence against women (Belknap 2001; Ogle and Jacobs 2002). While legal action was taken by many states during this time period to regulate the severity of wife abuse, for the most part battering continued largely unaddressed by the criminal justice system and the police (Gosselin 2000; Ogle and Jacobs 2002).

During the 20th century, the criminal justice system generally continued to ignore the issue of intimate partner violence (Buzawa and Buzawa 1996; 
Schechter 1982). In fact, an article published in the 1964 edition of the Archives of General Psychiatry entitled 'The Wifebeater's Wife: A Study of Family Interaction' (Schechter 1982, 21), illustrates the absence of terms such as 'battered woman' and 'victim' that are central to current understandings of intimate partner violence. Under the framing of intimate partner violence as a private issue, women were viewed to be partially, if not completely, accountable for any violence they experienced at the hands of their spouse and were thus often unable to receive needed legal and social assistance (Pleck 1987; Schechter 1982). Police officers received little to no training in handling abuse cases and most departments did not have concrete intimate partner violence policies in place.

During the 1960s, policies were implemented that encouraged police officers who responded to intimate partner violence calls to "calm the parties down' with the use of mediation (Belknap 2001, 293). For example, materials from the Michigan Police Training Academy during this time period encouraged officers to 'avoid arrest if possible' and 'state that your only interest is to prevent a breach of the peace' (Schechter 1982, 157). Thus, commonly when women called the police after being beaten by their partner, the calls were screened out or the police refused to arrest the batterer (Jaffe et al. 1993; Schechter 1982).

Intimate partner violence was first widely recognized as a serious social problem in the USA in the late 1960s and early 1970s due to the efforts of the battered women's movement (which was rooted in the second wave of the feminist movement). Feminists, community activists, professionals, and women who had been abused began to publicly characterize woman battering as a serious social concern. The battered women's movement directly challenged the dominant thinking of the time by arguing that intimate partner violence was not merely a private issue but a public, social, and political problem rooted in sexism and women's oppression (Schechter 1982). Efforts of the battered women's movement resulted in the establishment of safe houses and shelters for victims of intimate partner violence and the formulation of state and national task forces and coalitions. Furthermore, battered women's advocates demanded that the criminal justice system improve intimate partner violence policies and practices (Schechter 1982; Schneider 2000). These demands, coupled with a broader 'law and order' movement in the USA in the 1980s that advocated for harsher punishment towards crime in general, led to multiple reforms surrounding police response to intimate partner violence (Ford et al. 1996).

\section{Policing reforms}

Battered women's advocates have written, lobbied for, and assisted in implementing legislation in many states that has helped abused women receive better assistance. Many of the shifts in police practice stem from these legislative changes. According to a report by the Urban Institute 
(Burt et al. 1996) in the 1970s and 1980s, legislative reforms in many states included the codifying of intimate partner violence as criminal conduct; the creation of new offense categories to cover intimate partner violence incidents; the implementation of increased penalties for those convicted of intimate partner violence; the expansion of coverage of intimate partner violence statutes to include couples living together or having a child in common, and, in some jurisdictions, couples of the same sex; the creation of civil protection orders specifically for intimate partner violence; and the implementation of mandatory training about intimate partner violence for police and highway patrol officers and sheriffs.

On a federal level, in 1984 the Attorney General's Task Force on Family Violence found the need both for coordinated community responses to intimate partner violence and for specific reforms in laws and practices of the criminal justice system (Burt et al. 1996). The Violence Against Women Act was passed in 1994 as a result of the work of women's and civil rights groups. This legislation was groundbreaking in that it defined violence against women as violating a federally protected civil right. It also was instrumental in establishing funding to states and local governments to assist them in developing and strengthening law enforcement and prosecution strategies to combat violent crimes against women and to develop and strengthen victim services in cases involving violence against women (Burt et al. 1996).

From its origins, the battered women's movement criticized the reluctance of police departments and the criminal justice system to provide protection to battered women, while simultaneously demanding reforms (Buzawa and Buzawa 1996; Hilton 1993). In the 1970s, class-action lawsuits filed in several cities took issue with the lack of police response to intimate partner violence. For example, as Schechter (1982) describes, in 1976 battered wives filed a suit, Bruno v. Codd, against the New York City Police Department, the New York City Department of Probation, and the clerks of the Family Court. The lawsuit charged the police and courts with 'gross failure to comply with the law' (p. 160). The police settled out of court and agreed on a number of policy stipulations, including that they respond to all calls from battered women, arrest men who commit assault, and assist battered women in obtaining medical care.

In the $1980 \mathrm{~s}$, police response to woman battering continued to improve in the USA. Several forces contributed to this. Not only did the battered women's movement persist in its efforts to bring increased attention to the problem of intimate partner violence, but battered women also continued to successfully file class-action lawsuits against police departments who failed to arrest men who were violent (Belknap 2001). One of the most famous lawsuits was filed in 1984 by Tracey Thurman against the City of Torrington, Connecticut. Tracey Thurman was a battered woman who left her husband. He refused to grant her a divorce and continually harassed and threatened her for months, even after she filed for a restraining order 
against him. She called the police repeatedly yet they never picked him up. At one point Tracey's husband showed up to her house and beat her severely. Despite her call to the police, they did not respond immediately and when they did arrive, they failed to intervene in her beating (which was so severe that it led to permanent damage). She sued the police department and won. As a result of her lawsuit the governor of Connecticut formed a task force to examine the ways in which the state responded to intimate partner violence (Belknap 2001).

Another important factor that contributed to changes in police policy was the very influential Minneapolis experiment - a pioneer study conducted by Sherman and Berk (1984) that found that arresting batterers helped to prevent future violence. For this experiment, when police officers responded to an intimate partner violence call offenders were randomly assigned to three options: (i) arrest, (ii) mediation, or (iii) an order that the offender leave the location. The study found that those offenders who were arrested were the least likely to commit future violence. Because of these findings, many cities around the USA adopted policies that encouraged or even mandated arrest in intimate partner violence cases.

Mandatory and pro-arrest (or presumptive) policies are common today in the majority of jurisdictions in the USA. A mandatory arrest law requires the police to arrest an offender if there is probable cause to believe that intimate partner violence has occurred (Schneider 2000). Pro-arrest policies or presumptive policies encourage arrest but allow officers a bit more discretion. In the last two decades, numerous districts have adopted aggressive arrest policies: currently, 31 states have passed mandatory arrest laws (American Civil Liberties Union 2007). Such laws and policies remove the decision to press charges from the victim. They also reduce the likelihood that responding officers will use their own judgment to decide whether or not to make an arrest, which in the past, often resulted in inaction by many police officers. Policies that mandate or encourage arrest of abusers are seen as sending a message to police officers to 'take domestic assaults seriously; treat them criminally' (Gosselin 2000, 316). However, these policies have been the subject of much controversy and debate.

\section{Debates over reforms}

Mandatory arrest polices have been highly controversial, both in and outside of feminist circles. At issue are a number of questions, mainly: (i) Who should have control over what happens when the police respond to a intimate partner violence case: the state, the police, or the victim? (ii) Are mandatory arrest policies in the best interest of all victims? (iii) Do mandatory arrest policies have an impact on the behavior of perpetrators? In this section, I will review the central debates surrounding each of these questions and discuss what the research shows surrounding these issues. 
Mandatory arrest policies and issue of control

A central issue surrounding mandatory arrest policies is the issue of control. Because these policies either mandate or encourage police officers who respond to intimate partner violence calls to arrest the perpetrator, ostensibly the decision-making power about what happens to an offender is removed from both the victim and police and rests with the state. Many argue that this is a good thing and favor mandatory arrest policies because they help the state to send a uniform message to the community that intimate partner violence is a serious crime and is a matter of public concern instead of a private issue between the two people involved (Schneider 2000). Battered women's advocates in favor of mandatory arrest laws argue that such laws hold agents of the state such as police officers responsible for fulfilling the government's responsibility to protect its citizens (Stark 2004). Furthermore, as Stark (1993) states, 'making battering the only crime in which police discretion is removed acknowledges a special social interest in redressing the legacy of discriminatory treatment of women by law enforcement' (p. 662).

Others argue that removing or lessening responding police officers' decision-making powers through mandatory arrest policies is positive (see Stark 1993 for discussion). Such policies control the behavior of police officers and hold them accountable for taking action. Many feminists and battered women's activists see this is as beneficial given the typical police response of minimal or no action when they have responded to intimate partner violence calls in the past. Indeed, as Stark (1993) points out, arrests for assaults rose $70 \%$ from 1984 to 1989 due to the implementation of mandatory arrest laws.

Finally, some have also argued that having policies that mandate the arrest of abusers is helpful to victims because it takes the pressure off of victims to make the decision whether or not to arrest their batterer (see Stewart 2001 for discussion). This makes it less likely that batterers will hold victims responsible for their arrest and thus retaliate at a later date. Mandating arrest also helps to ensure that the offender will be arrested for breaking a law regardless of the wishes of the victim. Indeed, a study conducted by Buzawa and Austin (1993) revealed that the actions taken by police officers who respond to intimate partner violence calls were largely influenced by victims' preferences for what they wanted to have happen to their abusers. The officers were more likely to arrest a perpetrator if this is what the victim desired and less likely to arrest a perpetrator if it went against the victim's wishes. Supporters of mandatory arrest policies argue that these policies will help to ensure that all offenders of intimate partner violence are arrested.

Even though mandatory arrest policies are supposed to remove the discretion of police officers who respond to intimate partner violence calls and diminish the likelihood that police will respond negatively to victims, 
current research demonstrates that gender bias within the system still exists and that many female victims continue to have negative experiences with the police. For example, Stephens and Sinden (2000) found that the majority of battered women in their study who had more than one encounter with law enforcement officials for intimate partner violence reported that police officers commonly minimized the seriousness of their situation, doubted their story, conveyed attitudes of nonchalance and indifference, and/or were rude and condescending. Similarly, a study by Belknap and Hartman (2000) of victim advocates' reports found that while some advocates reported favorable police behaviors and responses, many believe that there are still a 'significant' portion of cases in which police response is unfavorable or even hostile.

Finally, not everyone believes that taking away control from battered women during the police response to intimate partner violence calls is a good thing; some argue that removing victims from major-decision-making roles in their cases is not always in the best interest of the women who experience intimate partner violence (Dasgupta 2003; Ford 1991; Hilton 1993; Mills 2003). Some researchers and battered women's advocates argue that mandatory arrest policies disempower women because they limit women's agency and ability to act in their own best interests, ignore their opinions, and revictimize them through forced submittal to state power (Ferraro and Pope 1993; Ford 1991; McLeod 1983). Many women who call the police do not want their batterer arrested (Ferraro and Pope 1993; Stewart 2001). There are multiple reasons a woman may not want her batterer to be arrested and/or jailed: she may depend on him for income and/or housing for herself and/or her children, she may be afraid he will be even angrier when he gets out of jail and his violence against her will escalate, she may not trust the system, she may prefer he receive counseling and support instead of prosecution and punishment, and/or she may not want to end her relationship with him. As Gelles (1993) argues, some women who do not wish their abuser to be arrested use their call to the police and/or the resulting police visit as a means of controlling their abuser's behavior. Because mandatory arrest policies remove this option from women, some have argued that they also remove power from abused women. And, as Rajah et al. (2006) point out, some see the removal of control from female victims as particularly problematic because 'women who are denied decision-making power in mandatory arrest encounters may be dissatisfied with the criminal justice response to intimate partner violence and discouraged form calling the police in future domestic disputes' (p. 899).

What does research show about how victimized women themselves view mandatory arrest policies and the amount of control they have in the police response to violence perpetrated against them? Studies indicate that there is mixed support from battered women for such policies. Smith (2001) surveyed 93 battered women staying at emergency shelters and 
found that while the majority of the women were supportive of mandatory policies, their support varied by race, marital status, and the extent of their injuries, suggesting that some women desire more control over the outcomes of their cases. For example, while $79 \%$ of the white women in her sample were supportive of the adoption of mandatory arrest policies, only $53 \%$ of the black women in her study were supportive of such policies, suggesting that 'Black women prefer more power and control over the arrest decision than White women' (p. 102). Single and divorced women were more supportive of mandatory arrest policies than married or separated women. Smith concludes that her findings lend support to the claim that universalistic policies are not likely the best means of addressing the individual needs of victims. Similarly, Bohmer et al. (2002), who conducted focus groups with both victims of intimate partner violence and service providers for intimate partner violence victims, found that while support for mandatory policies was mixed among the providers, clients were even less likely to support such policies. The foremost concern of the clients was 'their future financial and personal well-being' and they saw the criminal justice system as 'being an impediment to that future rather than a source of help' (p. 84). As one victim in this study stated of her abuser: 'Well I need him to pay the bills more than I need him to pay for the violence' (p. 82). Such findings have led to broader questions about whether or not mandatory arrest policies serve the best interests of all battered women.

\section{Mandatory arrest policies and victims' best interests}

Again, many argue that because mandatory arrest policies have led to police officers taking intimate partner violence more seriously, they are beneficial to battered women. The findings from a study conducted by Jones and Belknap (1999) suggest that the implementation of a pro-arrest policy in one jurisdiction served to improve the likelihood of a 'strong' police response to intimate partner violence. Epstein (1999) discusses a study conducted in 1990 in the District of Columbia that found that police officers who responded to intimate partner violence calls were arresting accused batterers in only $5 \%$ of all cases; furthermore, they failed to arrest in over $80 \%$ of cases where the victim had visible injuries. After the city implemented a mandatory arrest law, the rate of arrest of offenders by responding police officers rose from 5\% to 41\%. Epstein (1999) argues that mandatory arrest policies appear to benefit those victims who desire the arrest of their abusers. Furthermore, research also demonstrates that under mandatory arrest policies more intimate partner violence victims are reporting the violence that they experience to the police (Cho and Wilke 2005).

A number of critics of mandatory arrest policies have argued that these policies are not in the best interest of all abused women. A major argument 
stems from the recognition that abused women's experiences are diverse and multifaceted - there is no one universal victimized woman's experience. Some critics see uniform responses to intimate partner violence as problematic because such responses fail to take into account the diversity of women's situations based on structural factors such as race, culture, and class and individual factors such as different women's desires and needs (Crenshaw 1994; Dasgupta 2003; Mills 1996). For example, Epstein (1999) makes the argument that the recent reforms to immigration law in the USA may lead abused immigrant women to reject the criminal justice system as a means of addressing the violence in their lives because of fear that their abuser will be deported.

Similarly, some have argued that using arrest as the main means of addressing intimate partner violence exacerbates problems in minority and/or poor communities where police have often demonstrated inappropriate behavior and women may be mistrustful of the police (Sparks 1997). For example, Crenshaw (1994) argues that some women of color may be reluctant to call the police because they do not want to subject their abuser to a criminal justice system that has historically discriminated against men of color. Research on this topic has been mixed. One study cited by Epstein (1999) found that African American abused women worried that reporting abusers to the police 'could further contribute to the social stereotyping of black men as particularly violent' (p. 137). However, a 2000 study by Rennison and Welchans (as cited in Stark 2004) found that some women of color actually report their victimization at higher rates (67\% for black women and 65\% for Hispanic women) than other groups, including white women (50\%).

Still others who argue that mandatory arrest policies are not always in victimized women's best interests point to the increasing number of studies showing that a growing number of women are arrested under these policies. Evidence suggests that in some jurisdictions after mandatory arrest policies were implemented the number of women arrested for intimate partner violence substantially increased (Hirschel and Buzawa 2002; Miller 2001). For example, female aggregate felony intimate partner violence arrest rates increased more than 500\% in California from 1987 to 1997 (DeLeon-Granados et al. 2006). Dual arrests - where women are arrested along with their male partners and ex-partners - appear to be the most common scenario under which women are arrested for intimate partner violence (Finn and Bettis 2006). While a possible explanation for the rise in women's arrest rates for intimate partner violence is that their use of violence has increased (DeLeon-Granados et al. 2006), many scholars and battered women's advocates argue that this is not the case. For example, while acknowledging that some women who are arrested for intimate partner violence do actually assault their partners, Osthoff (2002) argues that many women are wrongly arrested for engaging in acts of self-defense or when their abusers falsely accuse them of violence. 
Indeed, a study conducted by Finn and Bettis (2006) that explored police officers' justifications for using dual arrest did find that even though police officers are required by law to fully investigate the context in which an act of intimate partner violence occurs, many are hesitant to do so. Finn and Bettis state that the officers 'for the most part, fail to take into consideration factors that would help [them] distinguish an assault that was part of an ongoing pattern of battering from one that was not' (p. 282). This is tied to a criticism of mandatory arrest policies that centers on what Stark (2004) terms the 'incident-specific understanding' of battering held by the criminal justice system (p. 1321). Under current practice, when police respond to an intimate partner violence call, they are required to make an arrest based on whether or not an incident of violence has occurred; thus, they often fail to take into consideration the context in which the abuse has occurred and the continuous cycle of control and abuse that is common to many abusive relationships.

\section{Mandatory arrest policies and effect on offenders' behavior}

Debate also exists surrounding if/how mandatory arrest policies impact the behavior of offenders and whether or not these policies actually prevent intimate partner violence. Once again, research examining the effectiveness of mandatory arrest policies in deterring future violence has produced contradictory results (Belknap 2001; Schmidt and Sherman 1996). As I previously discussed, in the 1980s Sherman and Berk's Minneapolis experiment showed that arresting batterers helped to serve as a deterrent to future violence and resulted in the implementation of mandatory arrest policies all around the USA (Schmidt and Sherman 1996). However, in the 1990s, replication studies of the Minneapolis experiment in six other cities reflected both deterrent and backfiring effects of arrest (Schmidt and Sherman 1996). For example, based on the replication studies, researchers concluded that: (i) arrest reduces intimate partner violence in some cities but increases it in others; (ii) arrest reduces intimate partner violence among employed people but increases it among unemployed people; and (iii) arrest reduces intimate partner violence in the short term but may increase it in the long run (Sherman 1992). These replication studies paint a very muddy and confusing picture regarding the effectiveness of arrest in deterring intimate partner violence. Sherman (1992) himself has retracted the importance of the results of his original Minneapolis experiment and argues that mandatory arrest laws should be repealed.

Other studies examining the success of mandatory arrest policies also have produced mixed results. Maxwell et al. (2002) found that while in general arrest is associated with a decrease in subsequent intimate partner violence, $40 \%$ of victims in their sample experienced repeat victimizations. They conclude that 'arresting suspects, although effective on average, is 
not a panacea for all victims of intimate partner violence' (p. 72). Simpson et al. (2006) argue that research on the impact of mandatory arrest policies on police actions and behavior is somewhat limited and the results are contradictory. They found that in the state of Maryland there was a significant and positive impact of legislation encouraging arrest on the likelihood of police officers to arrest offenders in intimate partner violence cases.

Some research suggests that mandatory arrest policies are not executed uniformly across all populations and that racial and class disparities exist surrounding responding police officers' decisions about who to arrest. For example, Avakame and Fyfe (2001) found that police are more likely to arrest an offender if the victim is a wealthy, white, older, suburban female. They also found that the police are more likely to arrest if the offender is African American, if the offender is under the influence of drugs and alcohol, if the assault accorded in a suburban or rural area (as opposed to an urban area) and if there was injury to the victim. The study of Maxwell et al. (2002) showed that according to official arrest records more men of color were likely to reoffend but if victim interviews were consulted than white men were more likely to reoffend. The authors argue that this discrepancy may be due to a greater willingness of African American women to call the police and a greater likelihood of police officers to arrest African American offenders. In their study, Simpson et al. (2006) found that the implementation of a mandatory arrest policy did not differentially impact the arrest probabilities for African Americans and whites.

Data from the Bureau of Justice Statistics indicate that the rate of nonfatal incidents of intimate partner violence dropped from 5.8 per 1,000 residents in 1993 to 2.6 per 1000 residents in 2004 (Catalano 2006). These data also show a 26\% decline between 1993 and 2004 in the number of females murdered by an intimate partner and a $45 \%$ decline in the number of males murdered by an intimate partner (Catalano 2006). Because many battered women end up killing their batterer in self-defense when they believe that the state has failed to protect them (Belknap 2001; Schneider 2000), it is possible that the decrease in the number of males murdered by an intimate partner is a sign that increased intervention by the criminal justice system has provided battered women with the resources they need to safely exit their abusive relationship without having to kill their abuser. However, these trends also may be the function of the increased efforts of the battered women's and shelter movement over the past several decades which have aided women in safely exiting violent relationships. As some critics have pointed out, the exact relationship between criminal justice reforms and the decrease in intimate partner violence is unclear (Dasgupta 2003). Thus, drawing specific conclusions from trends about the success or failure of criminal justice reforms such as mandatory arrest policies is risky at best. A recent study conducted by 
the National Institute of Justice determined that 'no one policy affects all groups the same way in terms of decreasing violence' (as cited in Dasgupta 2003, 9).

\section{Future directions}

How are we to make sense of the conflicting and contradictory findings of the numerous studies that examine mandatory arrest policies and their impact on victims and offenders? Given that the findings of most of these studies are not consistent, how can we determine whether or not mandatory arrest policies are successful in preventing intimate partner violence and whether they are beneficial to the victims of such violence? Returning to Johnson's $(2005,2006)$ argument that there are different types of intimate partner violence is useful when trying to answer these questions. The existence of different types of intimate partner violence likely helps to explain the lack of consistent findings surrounding the effects of mandatory arrest policies: the impact of arrest on perpetrators and/or victims may differ depending upon the type of intimate partner violence that exists in a relationship. Johnson and Ferraro (2000) argue, 'Partner violence cannot be understood without acknowledging important distinctions among types of violence, motives of perpetrators, the social locations of both partners, and the cultural contexts in which violence occurs' (p. 948). And obviously, if we cannot understand partner violence we cannot develop a response that will successfully reduce and eradicate partner violence.

Clearly, a more aggressive police response to intimate partner violence by the criminal justice system has helped to solidify the message that such violence is not socially acceptable. Evidence suggests that policies that encourage the arrest and prosecution of abusers help some victimized women in some instances. However, the creation of laws and policies that treat all intimate partner violence cases uniformly are problematic if they: fail to recognize the various types of domestic violence; place too much emphasis on particular incidents of violence; and fail to understand victim's experiences with violence in the context of their entire relationship (Mahoney 1994; Wittner 1998). Uniform policies appear unable to account for and address the complex nature of intimate partner violence and the diversity of abused women's needs, desires, and experiences. A growing number of studies seem to suggest that mandatory law enforcement policies do not always serve the best interests of all victimized women, nor do they appear to be the sole solution to stopping intimate partner violence and guaranteeing the safety of women who are abused. Research indicates that in some cases (such as those in which victimized women are arrested), mandatory arrest policies may do more harm for abused women than good.

Thus, it seems that if as a society we truly are invested in the idea of stopping intimate partner violence, several things are necessary. First, we 
need more research that looks at how the needs and desires of the victims of various types of intimate partner violence may differ and how these needs may be best met. Similarly, we need research that examines if/how mandatory arrest policies differently impact the various types of intimate partner violence. For example, research is needed to answer questions such as whether or not arrest is more effective for those who perpetrate situational couple violence than for those men who perpetrate intimate terrorism. Second, there needs to be more training for agents of the criminal justice system such as police officers to help them better understand and recognize the different types of violence and the dynamics and patterns of abuse that exist in violent relationships. As Johnson (2005) points out, the response and intervention strategies that are most successful in eradicating intimate partner violence will likely vary depending on the type of violence. Finally, we must question the value of mandatory policies that dictate the uniform treatment of all intimate partner violence cases and acknowledge that such policies have had many unintended consequences. Instead of uniform policies, we should encourage responses that recognize the complexity of intimate partner violence and victims' experiences. These are challenging tasks, for sure, but they are necessary in order to ensure the safety of all victims of intimate partner violence.

\section{Short Biography}

Amy Leisenring is Assistant Professor of Sociology at San Jose State University. She received her $\mathrm{PhD}$ from the University of Colorado at Boulder in 2004. Her current academic interests include gender, intimate partner violence, qualitative research methods, and identity processes. Her most recent publication, "Confronting "Victim" Discourses: The Identity Work of Battered Women' appeared in Symbolic Interaction.

\section{Note}

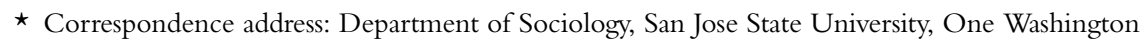
Square, San Jose, CA 95192-0122, USA. Email: amy.leisenring@sjsu.edu.

\section{References}

American Civil Liberties Union 2007. Domestic Violence: Protective Orders and the Role of Police Enforcement. http://www.aclu.org/womensrights/protectiveorders.pdf (last accessed 15 April 2007)

Archer, John 2000. 'Sex Differences in Aggression between Heterosexual Partners: A MetaAnalytic Review.' Psychological Bulletin 126: 651-80.

Avakame, Edem F. and James J. Fyfe 2001. 'Differential Police Treatment of Male-on-Female Spousal Violence: Additional Evidence on the Leniency Thesis.' Violence against Women 7: 22-45.

Belknap, Joanne 2001. The Invisible Woman: Gender, Crime, and Justice (2nd edn). Belmont, CA: Wadsworth.

Belknap, Joanne and Jennifer L. Hartman 2000. 'Police Responses to Woman Battering: Victim Advocates' Reports.' International Review of Victimology 1-3: 159-77.

Bohmer, Carol, Jennifer Brandt, Denise Bronson and Helen Hartnett 2002. 'Domestic Violence Law Reforms: Reactions from the Trenches.' Journal of Sociology and Social Welfare 29: 71-87. 
Burt, Martha R., Daryl Dyer, Lisa C. Newmark, Mary Norris and Adele V. Harrell 1996. Evaluation of the STOP Block Grants to Combat Violence against Women Act of 1994: 1996 Report. Washington, DC: The Urban Institute. http://www.urban.org/url.cfm?ID=306621 (last accessed 25 February 2007)

Buzawa, Eve S. and Carl G. Buzawa 1996. 'Introduction.' Pp. 1-13 in Do Arrests and Restraining Orders Work? edited by Eve S. Buzawa and Carl G. Buzawa. Thousand Oaks, CA: Sage Publications.

Buzawa, Eve S. and Thomas Austin 1993. 'Determining Police Response to Domestic Violence Victims: The Role of Victim Preference.' American Behavioral Scientist 36: 610-23.

Catalano, Shannon 2006. Intimate Partner Violence in the United States. Washington, DC: US Department of Justice, Bureau of Justice Statistics. http://www.ojp.usdoj.gov/bjs/intimate/ipv.htm (last accessed 15 April 2007)

Cho, Hyunkag and Dina J. Wilke 2005. 'How Has the Violence Against Women Act Affected the Response of the Criminal Justice System to Domestic Violence?' Journal of Sociology and Social Welfare 32: 125-39.

Crenshaw, Kimberle W. 1994. 'Mapping the Margins: Intersectionality, Identity Politics, and Violence against Women of Color.' Pp. 93-118 in The Public Nature of Private Violence, edited by Martha A. Fineman and Roxanne Mykitiuk. New York, NY: Routledge.

Dasgupta, Shamita D. 2003. Safety \& Justice for All: Examining the Relationship between the Women's Anti-Violence Movement and the Criminal Legal System. New York, NY: Ms. Foundation. http:// www.ms.foundation.org/user-assets/PDF/Program/safety_justice.pdf (last accessed 15 April 2007)

DeLeon-Granados, William, William Wells and Ruddyard Binsbacher 2006. 'Arresting Developments: Trends in Female Arrests for Domestic Violence and Proposed Explanations.' Violence against Women 12: 355-71.

Dobash, Russell P., R. Emerson Dobash, Margo Wilson and Martin Daly 1992. 'The Myth of Sexual Symmetry in Marital Violence.' Social Problems 39: 71-91.

Epstein, Deborah 1999. 'Redefining the State's Response to Domestic Violence: Past Victories and Future Challenges.' Georgetown Journal of Gender and the Law 1: 127-43.

Ferraro, Kathleen J. and Lucille Pope 1993. 'Irreconcilable Differences: Battered Women, Police and the Law.' Pp. 96-123 in Legal Responses to Wife Assault: Current Trends and Evaluations, edited by N. Zoe Hilton. Newbury Park, CA: Sage Publications.

Finn, Mary A. and Pamela Bettis 2006. 'Punitive Action or Gentle Persuasion: Exploring Police Officers' Justifications for Using Dual Arrest in Domestic Violence Cases.' Violence against Women 12: 268-87.

Ford, David A. 1991. 'Prosecution as a Victim Power Resource: A Note on Empowering Women in Violent Conjugal Relationships.' Law and Society Review 25: 313-34.

Ford, David, R. Reichard, S. Goldsmith and Mary Jean Regoli 1996. 'Future Directions for Criminal Justice Policy Domestic Violence.' Pp. 243-65 in Do Arrests and Restraining Orders Work? edited by Eve S. Buzawa and Carl G. Buzawa. Thousand Oaks, CA: Sage Publications.

Gelles, Richard J. 1993. 'Constraints Against Family Violence: How Well Do They Work?' American Behavioral Scientist 36: 575-85.

Gosselin, Denise K. 2000. Heavy Hands: An Introduction to the Crimes of Family Violence (2nd edn). Upper Saddle River, NJ: Prentice Hall.

Hilton, N. Zoe 1993. 'Introduction.' Pp. 3-8 in Legal Responses to Wife Assault: Current Trends and Evaluations, edited by N. Zoe Hilton. Newbury Park, CA: Sage Publications.

Hirschel, J. David and Eve Buzawa 2002. 'Understanding the Context of Dual Arrest with Directions for Future Research.' Violence against Women 81: 1449-73.

Jaffe, Peter D., Elaine Hastings, Deborah Reitzel and Gary W. Austin 1993. 'The Impact of Police Laying Charges.' Pp. 62-95 in Legal Responses to Wife Assault: Current Trends and Evaluations, edited by N. Zoe Hilton. Newbury Park, CA: Sage Publications.

Johnson, Michael P. 2005. 'Domestic Violence: It's Not about Gender - Or Is It?' Journal of Marriage and Family 67: 1126-30.

Johnson, Michael P. 2006. 'Conflict and Control: Gender Symmetry and Asymmetry in Domestic Violence.' Violence against Women 12: 1003-18.

Johnson, Michael P. and Kathleen J. Ferraro 2000. 'Research on Domestic Violence in the 1990s: Making Distinctions.' Journal of Marriage and the Family 62: 948-63.

Jones, Dana A. and Joanne Belknap 1999. 'Police Responses to Battering in a Progressive Pro-Arrest Jurisdiction.' Justice Quarterly 16: 249-73. 
Mahoney, Martha R. 1994. 'Victimization or Oppression? Women's Lives, Violence, and Agency.' Pp. 59-92 in The Public Nature of Private Violence, edited by Martha A. Fineman and Roxanne Mykitiuk. New York, NY: Routledge.

Maxwell, Christopher D., Joel H. Garner and Jeffrey Fagan 2002. 'The Preventive Effects of Arrest on Intimate Partner Violence: Research, Policy, and Theory.' Criminology and Public Policy 2: 51-80.

McLeod, Maureen 1983. 'Victim Noncooperation in the Prosecution of Domestic Assault.' Criminology 21: 395-416.

Mills, Linda G. 1996. 'Empowering Women Transnationally: The Case for Postmodern Interventions.' Social Work 41: 261-68.

Mills, Linda G. 2003. Insult to Injury: Rethinking Our Responses to Intimate Abuse. Princeton, NJ: Princeton University Press.

Miller, Susan L. 2001. 'The Paradox of Women Arrested for Domestic Violence: Criminal Justice Professionals and Service Providers Respond.' Violence against Women 7: 1339-76.

Ogle, Robbin S. and Susan Jacobs 2002. Self-Defense and Battered Women Who Kill: A New Framework. Westport, CT: Praeger Publishers.

Osthoff, Sue 2002. 'But, Gertrude, I Beg to Differ, a Hit is not a Hit is Not a Hit.' Violence against Women 8: 1521-44.

Pleck, Elizabeth 1987. Domestic Tyranny: The Making of Social Policy against Family Violence from Colonial Times to the Present. New York, NY: Oxford University Press.

Rajah, Valli, Victoria Frye and Mary Haviland 2006. 'Aren't I a Victim? Notes on Identity Challenges Relating to Police Action in a Mandatory Arrest Jurisdiction' Violence against Women 12: 897-916.

Schechter, Susan 1982. Women and Male Violence: The Visions and Struggles of the Battered Women's Movement. Boston, MA: South End Press.

Schmidt, Janell D. and Lawrence W. Sherman 1996. 'Does Arrest Deter Domestic Violence?' Pp. 43-53 in Do Arrests and Restraining Orders Work? edited by Eve S. Buzawa and Carl G. Buzawa. Thousand Oaks, CA: Sage Publications.

Schneider, Elizabeth M. 2000. Battered Women and Feminist Lawmaking. New Haven, CT: Yale University Press.

Sherman, Lawrence W. 1992. Policing Domestic Violence: Experiments and Dilemmas. New York, NY: Free Press.

Sherman, Lawrence W. and Richard A. Berk 1984. 'The Specific Deterrent Effects of Arrest for Domestic Assault.' American Sociological Review 49: 261-72.

Simpson, Sally S., Leana Allen Bouffard, Joel Garner and Laura Hickman 2006. 'The Influence of Legal Reform on the Probability of Arrest in Domestic Violence Cases.' Justice Quarterly 23: 297-316.

Smith, Alisa 2001. 'Domestic Violence Laws: The Voices of Battered Women.' Violence and Victims 16: 91-111.

Sparks, Anne 1997. 'Feminists Negotiate the Executive Branch: The Policing of Male Violence.' Pp. 35-52 in Feminists Negotiate the State: The Politics of Domestic Violence, edited by Cynthia R. Davies. Lanham, MD: University Press of America.

Stark, Evan 1993. 'Mandatory Arrest of Batterers: A Reply to Its Critics.' American Behavioral Scientist 36: 651-79.

Stark, Evan 2004. 'Insults, Injury, and Injustice: Rethinking State Intervention in Domestic Violence Cases.' Violence against Women 10: 1302-30.

Stephens, B. Joyce and Peter G. Sinden 2000. 'Victims' Voices: Domestic Assault Victim's Perceptions of Police Demeanor.' Journal of Interpersonal Violence 15: 534-47.

Stewart, Anna 2001. 'Policing Domestic Violence: An Overview of Emerging Issues.' Police Practice and Research 2: 447-59.

Straus, Murray A. 1999. 'The Controversy Over Domestic Violence by Women: A Methodological, Theoretical, and Sociology of Science Analysis.' Pp. 17-44 in Violence in Intimate Relationships, edited by Ximena B. Arriaga and Stuart Oskamp. Thousand Oaks, CA: Sage Publications.

Wittner, Judith 1998. 'Reconceptualizing Agency in Domestic Violence Court.' Pp. 81-104 in Community Activism and Feminist Politics: Organizing Across Race, Class, and Gender, edited by Nancy Naples. New York, NY: Routledge. 